\title{
Pycnodysostosis の 1 例と本邦報告例の統計的観察
}

\author{
武藤寿孝・北村完二*・道谷弘之・奥村一彦 \\ 松崎弘明 - 谷内健司 - 江上史倫 - 秋山幸生 \\ 中川哲郎・金澤正昭・村瀬博文* - 富田喜内*

\section{Pycnodysostosis: report of a case and review of the} \\ Japanese literature \\ Toshitaka Muto - Kanji Kitamura - Hiroyuki Michiya \\ Kazuhiko Okumura - Hiroaki Matsuzaki - Kenji Yachi \\ Fuminori Egami - Yukio Akiyama - Tetsuro Nakagawa \\ Masaaki Kanazawa - Hirofumi Murase - Kinai Tomita
}

\begin{abstract}
We reported a case of pycnodysostosis and review of 67 cases in the Japanese literature, especially on its oral and maxillofacial aspects. The following oral and maxillofacial findings were commonly reported in most cases: 1 . mandibular angle loss, 2. hypoplasia of the maxilla and mandible, 3. grooved palate and 4. malpositioned teeth. Other findings reported occasionally included: osteomyelitis, anterior cross bite, mandibular fracture, permanent tooth missing, hypercementosis, microdontia, delayed eruption of permanent tooth, persistence of deciduous tooth, enamel hypoplasia, obliterated pulp chamber, macroglossia, hypoplasia of dental root and dentin hypoplasia.
\end{abstract}

Key words: pycnodysostosis (ピクノディスオストーシス), oral findings (口腔内所見)

緒

言

1962年, Maroteaux \& Lamy ${ }^{1)}$ は大理石病様骨硬化像 と Cleidocranial dysplasia 様の頭蓋病変を合併した疾 患に Pycnodysostosis といら名称をつけた。しかし本邦 でもこれに先立ち 1954 年青池 ${ }^{3)}$ は同疾患をDysostosis petrosans と称して報告しているが，世界的にはPycnodysostosis の名称が主として用いられてきた，本症は

東日本学園大学粎学部口腔外科学第 1 講座

（主任 金澤正昭教授）

* 東日本学園大学蔽学部口腔外科学第 2 講座 (主任：村瀬博文教授)

First Department of Oral Surgery, School of Dentistry, Higashi-Nippon-Gakuen University (Chief: Prof. Masaaki Kanazawa)

* Secand Department of Oral Surgery, School of Dentistry, Higashi-Nippon-Gakuen University (Chief: Hirofumi Murase)

受付日：平成元年11月24日
小人症で頭蓋骨，顎骨と指趾末節骨の形成不全に加えて 全身的骨硬化と易骨折性を特徵とする常染色体劣勢遗伝 疾患である。これまでは主として整形外科領域で報告さ れてきたため口腔一顔面所見についての詳細な報告は少 ない.今回著者らは特徽的な本症の 1 例を経験したの で, 特にロ腔一顔面所見を詳細に検討し, 合わせて文献 的考察も行ったので報告する。

\section{症例}

患 者: 55歳 女性.

初 診: 昭和62年 6 月日日.

主 訴: $\sqrt{45}$ 部の自発痛と同部の骨露出.

家族歴：両親はまたいとこ同志の血族結婚である。兄 弟は13人括り，患者は一番上で，また 5 番目の妹が低身 長で患者と類似顔貌を呈し易骨折性であるといら。しか し妹は来院できず詳細は不明である。

既往歴：12藏頃より現在までに左右大摡骨, 脛骨と右 肩甲骨を計10回骨折している。易骨折性のため骨の異常 を指摘されていたが Pycnodysostosis の診断は昭和59年 


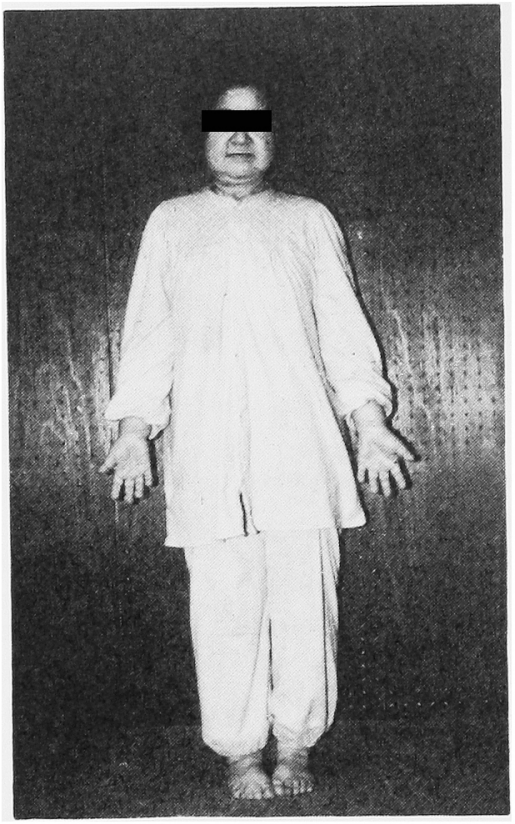

写真 1 全身像

に初めてなされた。

現病歴：初診約 1 年前より持続する $\sqrt{45}$ 部の拔歯後骨 露出と同部よりの排膿のため，某歯科医院より当科を紹 介され来院した。

現 症:

全身所見；身長 $125 \mathrm{~cm}$ ，夾高 $72 \mathrm{~cm}$ ，体重 $38.5 \mathrm{~kg}$ で 外観上は比較的均整のとれた小人症を星している（写真

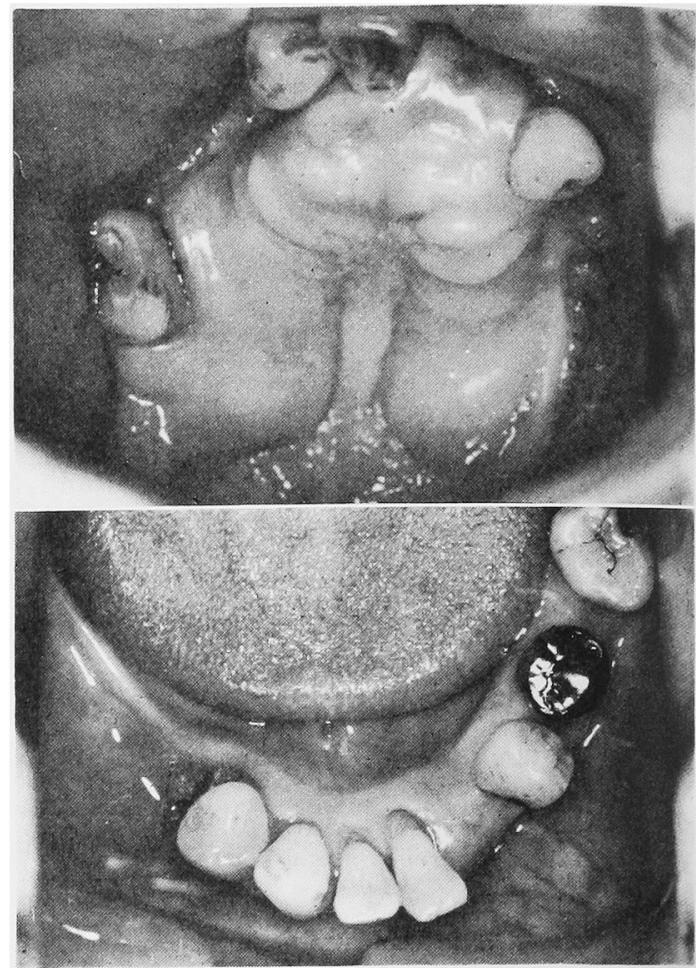

写直 3 口腔内写真，上顎と下顎

1).

頭部・顔面所見; 頭部において大泉門の開存を触知 し，前頭結節の膨隆は著明でないが長頭型である。颜部
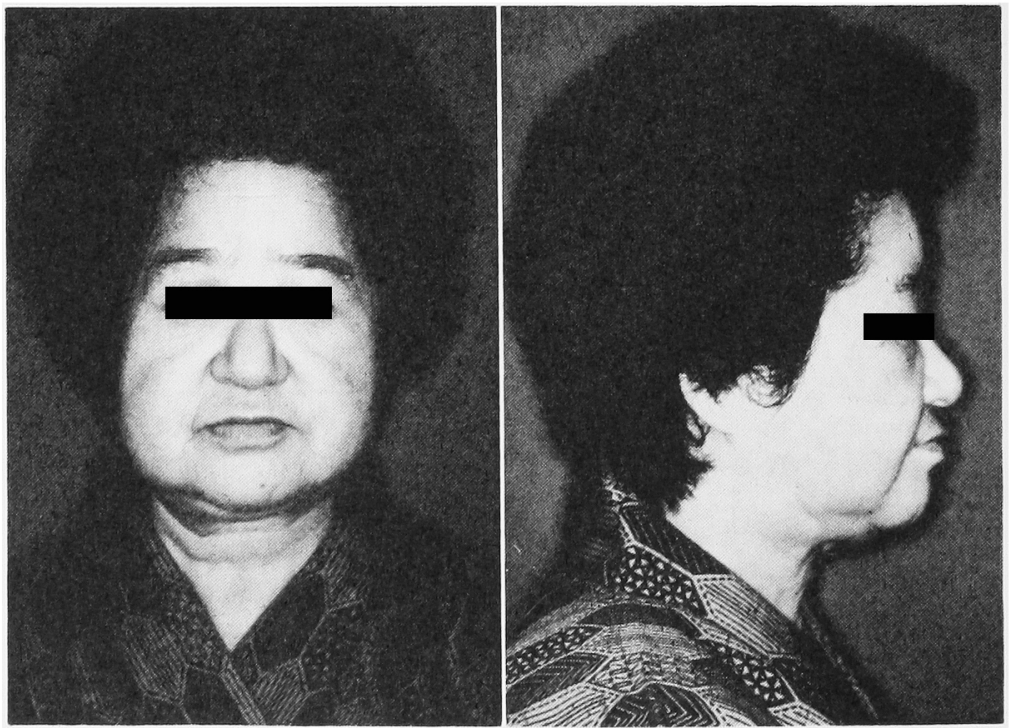

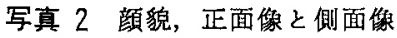




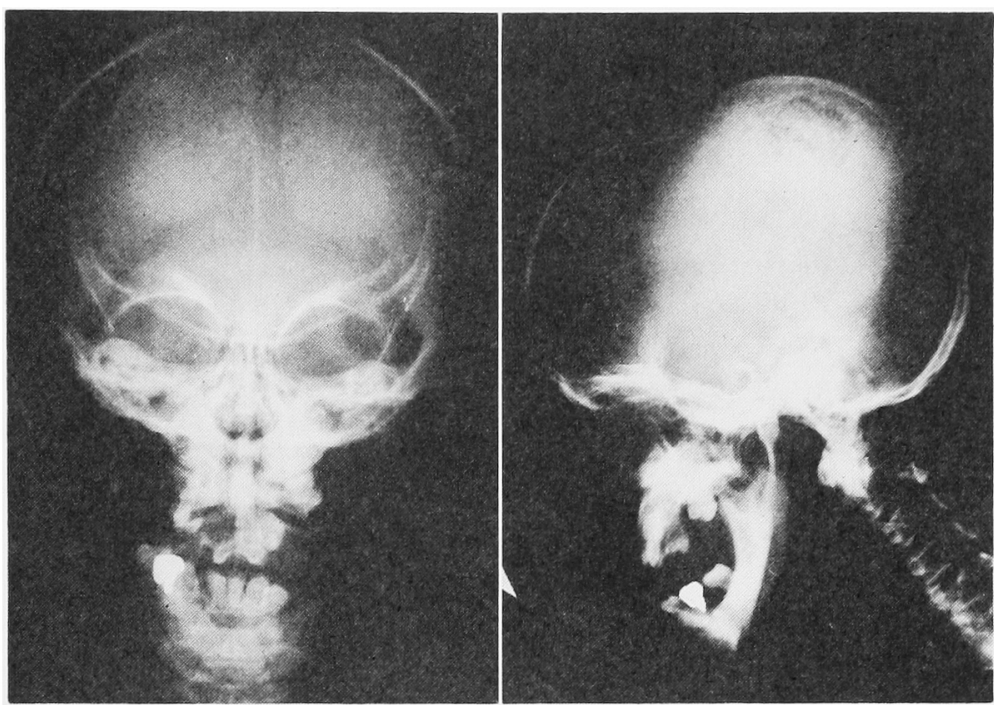

写真 4 頭部X楾写真, 正面像と側面像

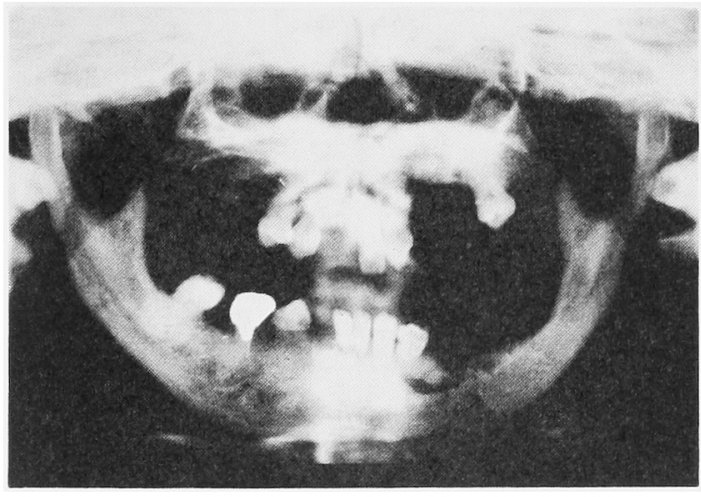

写真 5 バノラ マ X線写真像

においては眼球の軽度突出，我根部の陷凹，下靧角部の 消失を認める，正面顔貌はフクスケ様である（写真 2). なお開口障害は認めない。

口腔内所見；上下顎の歯槽弓は正常に比しかなり狭小 でまた口蓋の変形が著明である。すなわち口蓋は浅く 平坦化で, その中央のみが前後的に陷凹し，2本の緥溝を 認める。残存歯が少ないため歯列弓の形態は不明瞙であ るが上下顎とも歯軸の捻転，傾斜などの歯列不正がある. また上下顎前歯部の被蓋関係は反対であった，歯牙の大 きさは上顎歯で特にやや矮小米ぎみである（写真 3 ).

| 4 遠心部に直径約 $10 \mathrm{~mm}$ の黄白色の骨の露出と 4 | 部 煩側崡肉煩移行部に瘦孔を認める。

\section{$\mathbf{X}$ 線所見：}

頭蓋および顔面部；大小泉門，頭蓋縫合部の開存が著 明である，眼裔縁は陰影濃化を示し外上方に斜走してい る，上下顎骨の形成不全が著明で，上顎は㹟小でまた下

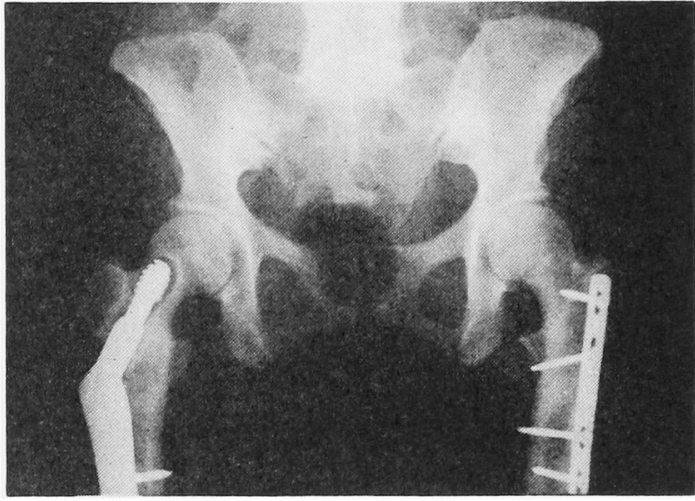

写真 6 骨盤部X楾写真像

顎骨の下㖽枝，下顎体部は細くなっておりとくに下顎角 の消失により下顎骨は直線状をなしている，前頭洞，蝶 形骨洞，上顎洞などの含気腔の形成は不良である（写真 4). パノラマX線写真像では, 下䫇切痕が深くくぼみ, 下效頭，筋突起が 細く長く見える。 12 の永久崡の久如 を認めるが，残存粘が少ないため他畔に関しては不明で ある.|可部の骨周囲に带状の透過像を認めた。 残存歯 牙根尖周囲の骨硬化像が著明で, また下筫骨の陰影濃化 もやや強く骨の硬化が考えられた（写真 5).

胸 部; 鎖骨の形成不全はないまた脊椎, 肋骨の骨 陰影濃化や形態異常は認めない。

長管骨；四肢長管骨はいずれもビマン珄陰影濃化を示 すが，骨髄腔の消失はなく，また骨幹端部扣よび骨端部 には密な海綿質骨梁構造を諗める。な括両側大腿骨近位 骨幹部には骨折後の金属補強物が認められた（写真 6 ）.

手部・足部; 手根骨, 足根骨扎よび短管骨のビマン性 


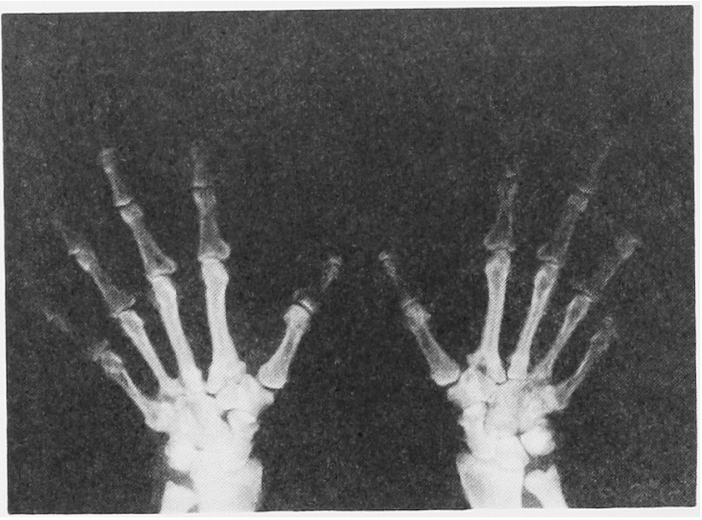

写真 7 手部 $\mathrm{X}$ 線写真像

骨陰影濃化に加え，指趾未節骨の溶解像が認められる。 また中手骨, 中足骨の短縮も認められる(写真 7).

臨床検查所見 ·血夜一般, 血掖生化学, 尿などの諸検 查で特に異常を認めなかったが，赤血球沈降速度の 1 時 間值が $123 \mathrm{~mm}$ と高値を示した。

骨シンチグラム：上下買骨の骨髄炎を起こしている部 分への集積を除き身体他部の骨への集積は認めない

処置および経過：Pycnodysostosis に生じた上下䫇骨

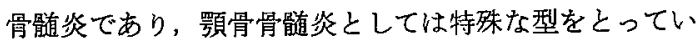
たため，治療経過も長期間を要した。この治療経過につ いては歯牙，靧骨の病理組織学的所見も含めてあらため て他誌に発表予定である。

\section{考察}

\section{Pycnodysostosis について}

硬化性骨硬化像を呈する osteopetrosis と鎖骨にあまり 異常を認めないが頭蓋病変が cleidocranial dysplasia K 類似している一連の疾患については，1946 年青池，石 塚泉に上り初めて報告された。 その後も同様な症状をる つ患者が島 ${ }^{5}$ ，伊藤ら ${ }^{6)}$ により報告されるに至り，青 池3,4) は内外で報告された症例を詳細に検討した。 そ してその臨床的特改は，(1)遗伝性である，(2)Dysostosis generalisata と同一の頭蓋奇形々顔貌を呈する，(3)四 肢，体幹が均整のと机た小人症，(4)鎖骨欠損または仍関 節はない，(5)指，趾末節が短縮して球状に膨隆する，(6) 易骨折性である，(7)全身の骨に広籍にビマン性骨硬化像 を呈するなどであり，造骨細胞障害と破骨細胞障害を併 せ持つ骨系統疾患であるとし，Dysostosis petrosansな る名称を提唱した。一方海外飞おいては，1962年 Maroteaux \& Lamy ${ }^{1}$ は上記の症状を呈する兄弟に発生した 2 例をPycnodysostosis の名称で報告した。青池の命名報 告が最初にもかかわらず，それ以後はこの一連の症候に ついては Pycnodysostosis という名称が国内外でともに 用いられるよらになった．本症の報告例は Elmore7) に

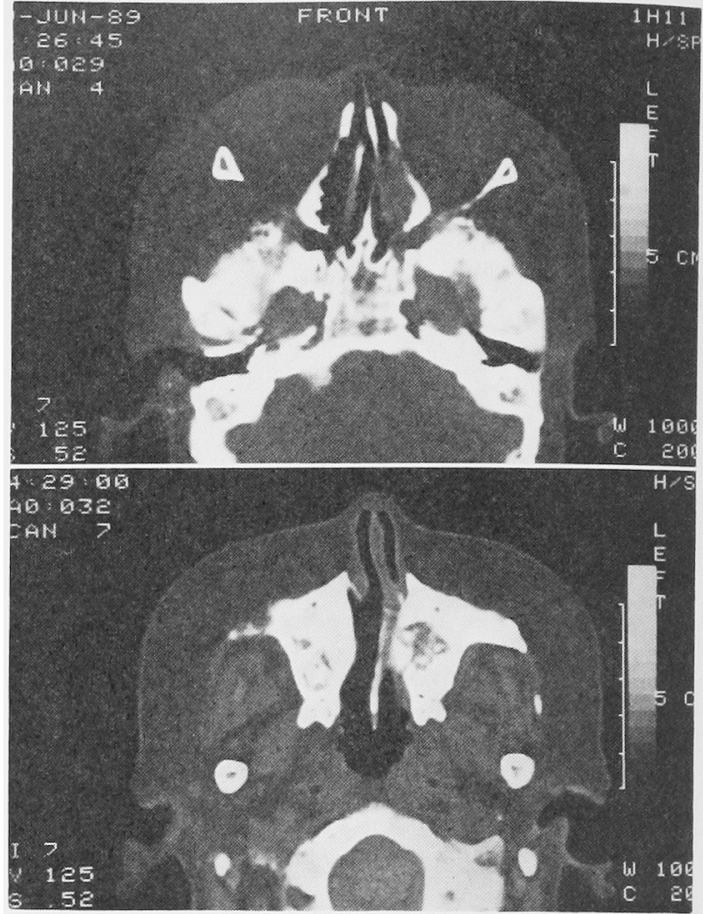

写真 8 頭部 $\mathrm{CT}$ ンキャン像

よれば1923 年の Montanari によるのが最初とされてい る。1968年 $\mathrm{Sedano}^{8)}$ は海外文献51家系73例を集計報告 している. 本邦に括いては1971 年杉浦ら 27 が 19 家系29 例, 1976年志村 ${ }^{37)}$ が29家系39例，1983年花沢 ${ }^{44)}$ が47 家系59例について統計学的報告を行っている，日本人と 外国人との発生頻度の差についての詳細は不明である が，本邦では諸外国上り多い上うに思われる，今回著者 らは自駼例を含め涉煫し得大本邦54家系67例飞ついて, とくにロ腔顔面の異常を含めて統計的に観察を行った (表1，2).

\section{2. 臨床所見について}

1）年龄・性：本邦報告例67例では, 最年少 3 か月, 最年長77歳で男性29例，女性38例であり男女比は $1: 1.3$ となりやや女性に多いようである。

2) 身 長: 低身長は特徴的な所見で，成人症例35例 でみると $120 \mathrm{~cm}$ から $150 \mathrm{~cm}$ の間にある．いずれの症 例沈括いても四肢, 体幹とも比較的均整のとれた小人症 である。

3）頭 部：頭蓋の大，小泉門および頭蓋縫合の開存 は全例に認められた。これらの所見は造骨細胞障害に起 因する骨形成不全と考えられる。その他トルュ鞍の形態 異常, 視力障害, 難㯖などがみられたとの報告すある.

4）鎖 骨: 部分欠損または形成不全のみられた症例 は15例と少ない，統計的観察では，頭蓋所見は Cleidocranial dysplasia と類似するが鎖骨の形成不全は必発症 
表 1 Pycnodysostosis の本邦報告例

\begin{tabular}{|c|c|c|c|c|c|c|c|c|c|c|c|c|c|}
\hline $\begin{array}{l}\text { 症 } \\
\text { 例 } \\
\text { 番 } \\
\text { 号 }\end{array}$ & 報 告 者 & $\begin{array}{l}\text { 報 } \\
\text { 告 } \\
\text { 年 }\end{array}$ & 龄 & 性 & $\begin{array}{l}\text { 身 } \\
\text { 長 }\end{array}$ & 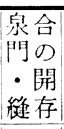 & $\begin{array}{l}\text { 骨漂 } \\
\text { 険 } \\
\text { 影 } \\
\text { の化 }\end{array}$ & $\begin{array}{l}\text { 指縮 } \\
\text { 趾 } \\
\text { の } \\
\text { 短大 }\end{array}$ & $\begin{array}{l}\text { 末容 } \\
\text { 節 } \\
\text { 骨 } \\
\text { の解 }\end{array}$ & $\begin{array}{l}\text { 鎖成 } \\
\text { 骨不 } \\
\text { の } \\
\text { 形全 }\end{array}$ & $\begin{array}{l}\text { 易 } \\
\text { 骨 } \\
\text { 折 } \\
\text { 性 }\end{array}$ & 両親の血族結婚 & 谕 \\
\hline 1 & 青池, 石塚 ${ }^{2)}$ & 1946 & 30 & $\mathrm{~F}$ & 132 & + & + & + & + & - & + & - & \\
\hline 2 & 島 $5^{5)}$ & 1950 & 17 & M & 128.5 & + & + & + & + & - & + & $+($ いこ $)$ & 症例 3 の弟 \\
\hline 3 & 島ら5) & 1950 & 20 & $\mathrm{~F}$ & 133.8 & + & + & + & + & - & + & $+($ & 症例 2 の姉 \\
\hline 4 & 伊藤, 佐買 ${ }^{6)}$ & 1952 & 18 & M & 134. 2 & + & + & + & - & - & + & $+(い と こ)$ & 症例5-7の兄 \\
\hline 5 & 伊藤，佐贯 ${ }^{6)}$ & 1952 & 16 & M & 130.1 & + & + & + & - & - & + & $+($ いこ $)$ & 症例 4 の弟 \\
\hline 6 & 伊藤, 佐貫6) & 1952 & 13 & M & 116 & + & + & + & - & - & + & $+(い と こ)$ & 症例 4 の弟 \\
\hline 7 & 伊藤, 佐貫6) & 1952 & 10 & M & 107.4 & + & + & + & - & - & + & $+(い と こ)$ & 症例 4 の弟 \\
\hline 8 & 䔎江 ${ }^{9)}$ & 1954 & 30 & M & 不明 & + & + & 不明 & + & - & + & 不明 & 症例 9 の兄 \\
\hline 9 & 䔎江 ${ }^{9)}$ & 1954 & 20 & $\mathrm{~F}$ & 不明 & + & + & 不明 & + & - & + & 不明 & 症例 8 の妹 \\
\hline 10 & 松永 $5^{10)}$ & 1962 & 21 & $\mathrm{~F}$ & 不明 & + & + & + & + & - & + & 不明 & \\
\hline 11 & 添田, 宗像 ${ }^{11)}$ & 1963 & 38 & $\mathrm{~F}$ & 130.5 & + & + & + & + & + & + & $+(い と こ)$ & \\
\hline 12 & 後藤ら ${ }^{12)}$ & 1963 & 9 & $\mathrm{~F}$ & 不明 & + & + & + & + & - & + & + & 症例 13,14 の妹 \\
\hline 13 & 後藤ら ${ }^{12)}$ & 1963 & 12 & M & 不明 & + & + & + & + & - & + & + & 症例12の兄 \\
\hline 14 & 後藤ら ${ }^{12)}$ & 1963 & 20 & M & 不明 & + & + & + & + & - & + & + & 症例12の兄 \\
\hline 15 & 田島ら & 1965 & 38 & M & 不明 & + & + & + & + & - & + & $+($ いこ & \\
\hline 16 & 暒井 5 ${ }^{14)}$ & 1965 & 7 & $\mathrm{~F}$ & 95.2 & + & + & + & + & - & + & $+(い と こ)$ & \\
\hline 17 & 中井 5 ${ }^{15)}$ & 1966 & 14 & M & 137.4 & + & + & + & + & - & + & - & \\
\hline 18 & 長尾 $5^{16)}$ & 1967 & 15 & M & 139. 4 & + & + & + & + & - & + & - & \\
\hline 19 & 村木ら17) & 1967 & 10 & $\mathrm{~F}$ & 103 & + & + & + & + & - & - & - & \\
\hline 20 & 小林ら ${ }^{18)}$ & 1967 & 6 & $M$ & 107.3 & + & + & + & + & - & - & + & \\
\hline 21 & 糸原ら 19$)$ & 1968 & 21 & $\mathrm{~F}$ & 120 & + & + & + & + & - & + & $+($ いこ $)$ & 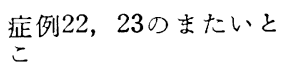 \\
\hline 22 & 系原ら & 1968 & 29 & $\mathrm{~F}$ & 135.5 & + & + & + & + & - & - & +（またいとこ） & 症例21のまたいとこ \\
\hline 23 & 系原 $5^{19)}$ & 1968 & 37 & M & 142 & + & + & + & + & - & + & +（またいとこ） & 症例22の兄 \\
\hline 24 & 准田 $5^{20)}$ & 1969 & 39 & M & 不明 & + & + & + & + & + & + & $+(い と こ)$ & \\
\hline 25 & 二武, 渡边 ${ }^{21)}$ & 1969 & 18 & $\mathrm{~F}$ & 132 & + & + & + & + & - & + & - & \\
\hline 26 & 菅 $5^{22)}$ & 1970 & 30 & $\mathrm{~F}$ & 131 & + & + & + & + & - & + & - & \\
\hline 27 & 根岸ら & 1970 & 8 & M & 112. 4 & + & + & + & + & - & + & - & \\
\hline 28 & 柴田，松矢 ${ }^{24)}$ & 1970 & 19 & $\mathrm{~F}$ & 140 & + & + & + & + & - & + & $+(い と こ)$ & \\
\hline 29 & 白石, 松永 ${ }^{25,26)}$ & 1971 & 19 & $\mathrm{~F}$ & 145 & + & + & + & + & & + & $+(い と こ)$ & \\
\hline 30 & 白石, 松永 ${ }^{25,26)}$ & 1971 & 23 & $\mathrm{~F}$ & 147 & + & + & + & + & + & - & 不明 & 症例31の第 2 子 \\
\hline 31 & 白石, 松永 ${ }^{25,26)}$ & 1971 & 68 & M & 148 & + & + & + & + & + & + & 不明 & 症例30の父 \\
\hline 32 & 杉浦, 洪 ${ }^{27)}$ & 1971 & 5 & M & 100 & + & + & + & + & - & + & $+($ いここ) & \\
\hline 33 & 杉浦, 洪 $5^{27)}$ & 1971 & 10 & $\mathrm{~F}$ & 118 & + & + & + & + & - & + & $+($ いこ $)$ & \\
\hline 34 & 杉浦, 洪 $5^{27)}$ & 1971 & 11 & $\mathrm{~F}$ & 127.5 & + & + & + & + & - & + & + & \\
\hline 35 & 杉浦，洪 ${ }^{27)}$ & 1971 & 17 & $\mathrm{~F}$ & 135 & + & + & + & + & + & + & - & \\
\hline 36 & 杉浦，洪ら 27$)$ & 1971 & 18 & $\mathrm{~F}$ & 131 & + & + & + & + & - & + & + & \\
\hline 37 & 杉浦，洪 ${ }^{27)}$ & 1971 & 53 & $\mathrm{~F}$ & 117.5 & + & + & + & - & - & + & $+(い と こ)$ & \\
\hline 38 & 藤谷ら 28$)$ & 1971 & 9 & $\mathrm{~F}$ & 122 & + & + & + & + & - & + & $+($ いこ $)$ & \\
\hline 39 & 瀬野 ${ }^{29)}$ & 1971 & 43 & M & 不明 & + & + & + & + & - & + & $+($ いこ $)$ & \\
\hline 40 & 菱田 $5^{30)}$ & 1973 & 10 & $\mathrm{~F}$ & 113 & + & + & + & + & - & + & - & \\
\hline 41 & 伊地知 ${ }^{311}$ & 1973 & 32 & $\mathrm{~F}$ & 130 & + & + & + & + & - & + & $+($ いこ $)$ & \\
\hline 42 & 斎藤 ${ }^{32)}$ & 1973 & 77 & $\mathrm{~F}$ & 126 & + & + & + & + & + & + & - & \\
\hline 43 & 田辺 $5^{33)}$ & 1973 & 17 & M & 150 & + & + & + & + & - & + & - & 症例 44 の弟 \\
\hline 44 & 田辺 ${ }^{33}$ & 1973 & 23 & $\mathrm{~F}$ & 143 & + & + & + & + & - & + & - & 症例 43 の姉 \\
\hline
\end{tabular}




\begin{tabular}{|c|c|c|c|c|c|c|c|c|c|c|c|c|c|c|}
\hline $\begin{array}{l}\text { 践 } \\
\text { 例 } \\
\text { 番 } \\
\text { 号 }\end{array}$ & 報 告 者 & $\begin{array}{l}\text { 報 } \\
\text { 告 } \\
\text { 年 }\end{array}$ & $\begin{array}{l}\text { 年 } \\
\text { 龄 }\end{array}$ & 性 & $\begin{array}{l}\text { 身 } \\
\text { 長 }\end{array}$ & $\mid$\begin{tabular}{|c|}
$\mid$ 泉合 \\
門の \\
的開 \\
䋖存
\end{tabular} & $\begin{array}{l}\text { 骨漕 } \\
\text { 䧔 } \\
\text { 影 } \\
\text { の化 }\end{array}$ & $\begin{array}{l}\text { 指縮 } \\
\text { 趾 } \\
\text { の肥 } \\
\text { 短大 }\end{array}$ & $\begin{array}{l}\text { 末溶 } \\
\text { 節 } \\
\text { 骨 } \\
\text { の解 }\end{array}$ & $\begin{array}{l}\text { 鎖成 } \\
\text { 骨不 } \\
\text { 不 } \\
\text { 形全 }\end{array}$ & $\begin{array}{l}\text { 易 } \\
\text { 骨 } \\
\text { 折 } \\
\text { 性 }\end{array}$ & 両親の血族結婚 & 備 & 考 \\
\hline 45 & 田辺 $5^{33)}$ & 1973 & 27 & $\mathrm{~F}$ & 不明 & + & + & + & + & - & - & 不明 & & \\
\hline 46 & 山田 ${ }^{34)}$ & 1973 & 27 & $\mathrm{~F}$ & 132.5 & + & + & + & + & - & + & - & & \\
\hline 47 & 山田 $5^{34)}$ & 1973 & 46 & M & 139 & + & + & + & + & - & + & + & & \\
\hline 48 & 石田 $5^{35)}$ & 1974 & 20 & $\mathrm{~F}$ & 135.5 & + & + & + & + & - & + & $+($ いこ $)$ & & \\
\hline 49 & 岸 $5^{36)}$ & 1974 & 10 & $\mathrm{~F}$ & 110.5 & + & + & + & + & + & - & $+(い と こ)$ & 症例50の姉 & \\
\hline 50 & 岸ら ${ }^{36)}$ & 1974 & 8 & M & 99.2 & + & + & + & + & + & - & $+($ いこ $)$ & 症例 49 の弟 & \\
\hline 51 & 志村 5 ${ }^{37)}$ & 1975 & 37 & M & 138.5 & + & + & + & + & + & - & $+($ いこ $)$ & & \\
\hline 52 & 西山ら ${ }^{38)}$ & 1977 & $3 \mathrm{~m}$ & M & 57 & + & + & 不明 & & + & - & - & & \\
\hline 53 & 西山5 ${ }^{38)}$ & 1977 & $7 \mathrm{~m}$ & $\mathrm{~F}$ & 64.5 & + & + & 不明 & + & - & - & - & & \\
\hline 54 & Kawahara ${ }^{39)}$ & 1977 & 32 & $\mathrm{~F}$ & 135.8 & + & + & + & + & + & + & $+(い と こ)$ & & \\
\hline 55 & 中田, 横田 ${ }^{40)}$ & 1977 & $7 \mathrm{~m}$ & M & 68 & + & + & + & + & + & - & $+($ & & \\
\hline 56 & 岸 $5^{41)}$ & 1979 & 10 & $\mathrm{~F}$ & 124.4 & + & + & + & + & 不明 & - & + & & \\
\hline 57 & 兼松 $5^{42)}$ & 1980 & 54 & $\mathrm{~F}$ & 131.8 & + & + & + & + & - & + & $+(い と こ)$ & 症例58の姉 & \\
\hline 58 & 兼松 $5^{42)}$ & 1980 & 51 & F & 134.6 & + & + & + & + & - & + & $+(い と こ)$ & 症例57の妹 & \\
\hline 59 & Takeuchi ${ }^{43)}$ & 1980 & 14 & M & 139 & + & + & + & + & + & + & $+(い と こ)$ & & \\
\hline 60 & Takeuchi ${ }^{43)}$ & 1980 & 39 & $\mathrm{~F}$ & & + & + & + & + & + & - & $+(い と こ)$ & & \\
\hline 61 & 花沢 544) & 1983 & 11 & M & 125 & + & + & + & + & + & + & - & & \\
\hline 62 & 藤井 5 ${ }^{45)}$ & 1983 & 27 & $\mathrm{~F}$ & 不明 & 不明 & 不明 & 不明 & 不明 & 不明 & & 不明 & & \\
\hline 63 & 今井 5 ${ }^{46)}$ & 1983 & 22 & $\mathrm{~F}$ & 126.5 & + & + & + & 不明 & 不明 & & 不明 & & \\
\hline 64 & 矢島 5 47 & 1985 & 33 & M & 149 & + & + & + & + & - & + & $+(い と こ)$ & 症例65の兄 & \\
\hline 65 & 矢島 $5^{47)}$ & 1985 & 31 & M & 150 & + & + & + & + & 不明 & + & $+(い と こ)$ & 症例64の弟 & \\
\hline 66 & 安田 ${ }^{48)}$ & 1988 & 20 & M & 136.5 & + & + & + & + & - & + & $+(い と こ)$ & & \\
\hline 67 & 自験例 & 1889 & 55 & $\mathrm{~F}$ & 125 & + & + & + & + & - & + & 十（またいとこ） & & \\
\hline
\end{tabular}

状ではなく，本邦報告例でも15例（22.4\%）にみられる のみであり，明確にこれとは異なると考えられる。

5 ）全身骨格の陰影濃化之易骨折性：四肢, 体幹の骨 の陰影浱化は全症例に認められ, これも本症の特徽的所 見である。自験例に打いては椎骨，骨盤の陰影濃化は明 賖でなかった。この長管骨の骨硬化像は osteopetrosis と 類似するか，骨幹端部の帯状陰影，骨䯣腔の消失はな い。また骨幹中央部の骨皮質の肥厚による骨硬化像を特 徵とする Engelmann disease とも異なる。この骨硬化 に起因して発生する易骨折性はほぼ必発症状て53例（79 \%)にみられている。骨折部位は自験例でもそうであ ったが下肢に多いようである。顎骨骨折は少なく青池 $ら^{2)}$, 田島 ${ }^{13)}$, 兼松ら ${ }^{42)}$ の 4 例にみられている。また 骨折の回数も頻回のケースが多く, 伊地知ら ${ }^{31}$ は31回の 骨折をきたした症例を報告している，自騟例に批いても 10回の骨折の既往を有していた。

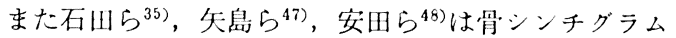
による全身骨への高集積を報告しているが，自験例にお

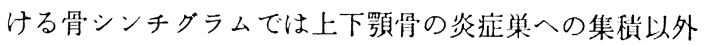
は認めなかった。

6) 手部・足部：指趾末節骨の溶解性変化は記截の不 明瞭な伊藤, 讃岐, 添田, 宗像, 系原らの報告例を除き
全例に認められている所見である。その部位扰よび程度 は症例により異なっている。杉浦ら ${ }^{27}$ は 3 例の小胃例に ついて 4 年ないし 8 年間のX線追跡を行い，末節骨の容 解性变化は出生直後からの恒状的な形成不全ではなく, 一旦形成された末節骨が尖端部から徐々に吸収される退 行性の変化であると報告している。ささらに西山ら ${ }^{38)}$ も自 験の 2 例で同様な結果を得ている.

7 ）口腔・顔面部：本症の特改的臨床症状が易骨折性 であるため整形外科，小兒科領域からの報告が大部分で あり，幽科領域からの報告は少ない。このため口腔内所 見についての詳細な報告が少ないが，記载のある所見に ついてまとめてみた（表 2).

(a上頢部; 全例に報告されている症状として上靧骨形 成不全に伴ら狭小な上䫇骨, 低口蓋とそれに伴ら正中部

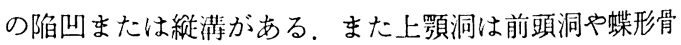
洞にみられたと同じく，明暸な含気腔を呈さないとの報 告が多い，自験例の CT 所見では，上買洞および蝶形 骨洞は斑点状の不均一な陰影像となっていた（写真 8).

(b)下顎部; 下顎骨の変化は Pycnodysostosis の全例飞 認められるもので, 下顎骨は全体に細く下顎角は消失し て直線状の長管骨様である。 また下頡切痕は深く関節 頭，筋突起は細長く見える。㑡貌X線写真で一目眿然で 
表 2 Pycnodysostosis の口腔㕹面所見

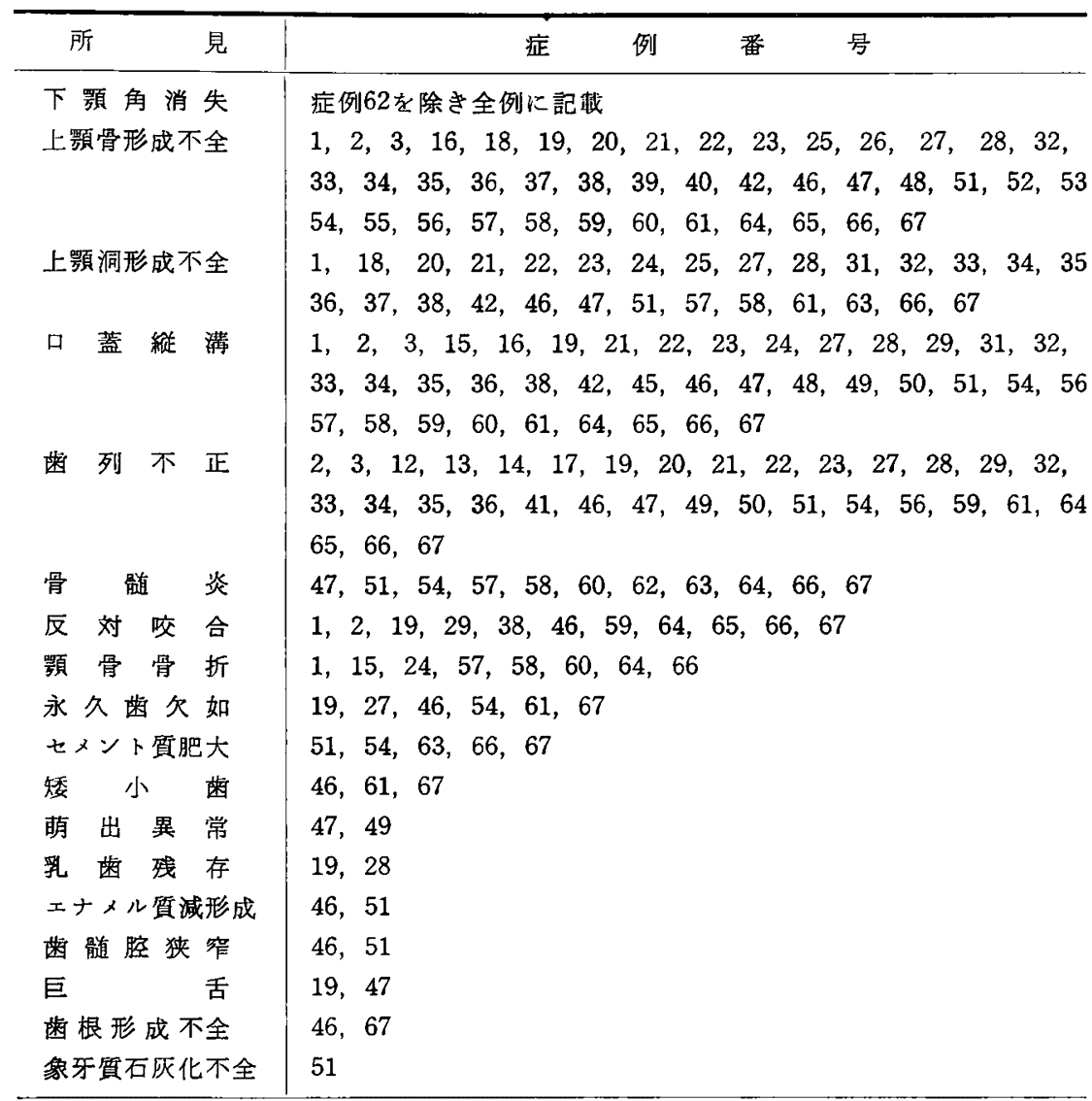

表 3 自験例の增冠の大さき（藤田 ${ }^{51)}$ の平均値の記裁と比較）

\begin{tabular}{|c|c|c|c|c|c|c|c|c|c|c|c|}
\hline & & $\underline{3}$ & 11 & $\underline{3}$ & $\underline{7}$ & $\overline{7} \mid$ & $\overline{4}$ & $\overline{1}$ & $\sqrt{1}$ & $\sqrt{3}$ & $\overline{4}$ \\
\hline & 自験例 & 7. 7 & 8.3 & 7.7 & 8.8 & 9.8 & 7.3 & 5.2 & 5.4 & 6.7 & 7.4 \\
\hline & \{平 均 & 7. 9 & 8.6 & 7.9 & 9.6 & 11.6 & 7.1 & 5.4 & 5.4 & 6.7 & 7.1 \\
\hline \multirow{2}{*}{ 厚ざ } & |自験例 & 7.6 & 7.4 & 7.8 & 10 & 10.5 & 7.8 & 6.2 & 5.8 & 7.5 & 7.9 \\
\hline & \{平 均 & 8.3 & 7.2 & 8.3 & 11.6 & 10.9 & 7.7 & 5.7 & 5.7 & 7.6 & 7.7 \\
\hline
\end{tabular}

単位: $\mathrm{mm}$

あるが，上下顎骨の発育不全が認められるが，上下顎の 咬合関係では反対咬合を呈するとの報告が多い(11例). 本症例に批いても残存歯が少なく，田歯部については不 明であるが前歯部においては反対咬合であった。 また上 下前歯の唇側傾斜む強く，これは䂓骨に配列する歯牙 （自験例では，残存歯牙の幅径は正常值よりやや小さい： 後述）との大きさの不均衡によるものと考えられる。さ らにオトガイ形成不全も認められるため，側貌は強い Convexity となり鳥貌に見える症例が多い上うである。 しかし自験例ではX線写真状 Convexity となっている
が鳥貌とはいえない側貌であった，下䚑骨の陰影濃化に よる骨硬化性変化については記載されているものが非常 に少なく明らかでなかった。しかし本症の特徵が全身の 骨の陰影濃化であることから上下顎骨にも同様な変化が あると考えられる，自験例をみると上下顎歯牙根尖周田 部の硬化像に加えて, とくに下顎枝辺縁皮質骨, 海綿質 骨内に陰影濃化を認めた。 また手術所見によってもこの 骨硬化は確認された。

〔歯牙所見；前記したように顎骨と齿牙との大きさの 不均衡のため米列不正は上下顎とも全例に認められてい 
る、矮小歯の報告があるが，自験例の残存粦の計测では

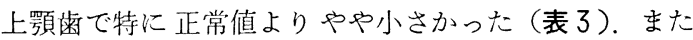
自験例にもみられたが志村ら ${ }^{37)}$, Kawahara $5^{39)}$, 安田 ら ${ }^{48)}$ はセメント質肥大を認めている。この変化は弱年者 にはみられないことより経年的な進行性のものではない かと推論される。その他, 乳歯残存, 永久歯の欠如（自 験例は $\sqrt{2}$ に認めた)，歯髄腔狭窄などが報告されてい る。

(d)骨䯣炎の発生；口腔内はウ蝕，歯周病が起こりやす いために，また本症は靧骨の骨硬化性変化があるため一

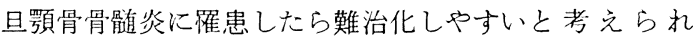
る。本邦では自駼例を含め10例が報告されており，いず れも慢性，難治化している，同様に骨硬化性変化を示す 疾患に大理石病があるが，やはり顎骨骨䯣炎に罹患する と治嘴しにくいと報告されている ${ }^{49,50)}$. 自験例に発生し た罘骨骨䯣炎の治療も長期沉んだがその経過について は別誌に掲載予定である。

8 ）遗伝性：両親の血族結婚例は自験例を含め，本邦 報告例の 43 例 $(64 \%)$ にみられた。自験例では両親がまた いとこであり，5番目の次女が同症状をもっているとい らが確認できなかった。現在本症の遗伝性については， (1)雨親は罹患していない, (2)同胞発生例が多い, (3)近親 結婚例が高いことなどから常染色体性劣性遗伝であると いわれている。青池 ${ }^{3)} は 1954$ 年，すでに内外の報告例を 分析し，劣性遗伝であるらと述べていた。

\section{3. 病理組織学的所見}

1) 骨組織所見: 青池 ${ }^{3}$ は自験例の下䫇骨骨折部より 採取した骨を病理組織学的に検索した。そして骨採取時 の骨は異常に硬く，その組織像はあきらかなモザイク構 造を呈する層板からなり，Haver 氏管は小さく，中に血 管を認めるものが多いが，骨小窝の中は空虚で骨細胞は 認めなかったと報告している。しかし杉浦ら ${ }^{27)}$ は腸骨よ りの骨採取所見では，骨硬度はほぽ正常でありまた組織 学的にも特に異常を認めていない，本症はX線的に，特 に長管骨に骨硬化像を呈するのを特徵としているため, X線像で硬化像を認める骨では青池の述べている Haver 氏管の狭小化と骨芽細胞，破骨細胞の減少はあるだろら と推定される。自験例に拈忛る顎骨骨䯣炎の腐骨摘出手 術所見では，炎症性刺湤も考兄られるが骨硬化は強く認 められた。

2) 歯牙所見：歯牙所見についての記載は少なく, Kawahara $5^{39}$, 志村 ${ }^{37)}$, 安田 ${ }^{18)}$ の報告をみるのみ である. Kawahara らは根尖性セメント質嗹を, 志村ら は象牙質の軽度石灰化不全, 歯䯇腔の狭窄と第二セメン 卜質の過形成を，また安田らは歯根全周に及ぶ著しい第 二セメント質の肥厚を報告している。自験例でも数歯に セメント質の肥厚を認めた。岸ら ${ }^{11}$ はこのセメント質の 肥厚は若年者には認められないため，骨硬化性变化と同 様に経年的変化ではないかと述べている。
結

語

55歳, 女性の Pycnodysostosis の 1 例を経験し，症例 の概要を報告するとともに本邦54家系67症例について， とくにロ腔内所見を含めた文献的考察を行った。

\section{引用 文 献}

1) Maroteaux, P. and Lamy, M.: La Pycnodysostose. Press Med 70: 999-1002 1962.

2）青池勇雄, 石塚廣行：大理石骨病について(抄) 粎科学雑誌 3: 1421946

3）青池勇雄：新しい遗伝性骨疾患。外科の領域 2: 763-765 1954

4) Aoike, I.: On a New Heriditary Bone Disease: A combined type of Dysostosis Generalisata and Osteopetrosis. Bull Tokyo Med Dent Univ 5: 19-31 1958.

5）島啓吾, 百武進, 他: 先天性骨形成障害を 有する一疾患に就て。日整会誌 23：174-180 1950 .

6）伊藤鉄夫，佐貫和正：大理石骨病の 4 兄弟につ いて。整形外科 3：135-1391952.

7) Elmore, S.M.: Pycnodysostosis-A Review. J Bone and Joint Surg 49-A: 153-162 1967.

8) Sedano, H.D., Gorlin, R.J., et al.: Pycnodysostosis. Amer J Dis Child 116: 70-77 1968.

9）莲江民彦：骨折しやすい骨形成障害を有する 1 疾患（抄）、日整会誌 28：716 1954 .

10）松永 仁，市川将美，他：先天性骨系統疾患の 1 例 (Dysostosis generalisata と Osteopetrosis の合併症）（抄）。日整会誌 36：995 1962.

11）添田勝教, 宗像富士夫：Dysostosis generalisata そ Osteopetrosis の合併症について。整形外科 14: 103-111 1963.

12）後藤 澄, 稲田嘉孝, 他: 家族的発生を見た大 理石骨病例。整外之災外 12：89-92 1963.

13）田島時博, 由良忠, 他: Dysostosis Petrosans の 1 例 (抄)。口科誌 14: 2471965 .

14) Kajii, T., Homma, T., et al.: Pycnodysostosis. J Pediat 69: 131-133 1966.

15）中井義消 : Dysostosis generalisata と思われる 1 症例。小坚科臨床 19：1543-1547 1966.

16）長尾大, 五十嵐良雄, 他: Pycnodysostosis (Dysostosis petrosans). 小坚科䛦療, 30：891001967

17）村木悦子, 野呂成子, 他: Pycnodysostosis 汇口 いて。 日小児誌 71：250-258 1967.

18）小林昭夫, 武内惠子, 他 : Pycnodysostosis $の 1$ 例。 日小児誌 71：536-542 1968 .

19）系原 学, 梁 復興, 他: Pycnodysostosis $の 3$ 症例について，中部整災誌 11：255-258 1968.

20）鹤田登代志, 三井貞三, 他 : Dysostosis Petrosans 91 例 (抄). 日整会誌 39:929 1969. 
21）二武敏雄, 隻辺一郎: Pycnodysostosis の 1 例. 整外と災外 18：193-196 1969.

22）菅 正隆，木下 博，他: Pycnodysostosis につ いて. 整形外科 21：1021-1028 1970.

23）根岸宏邦, 大石康男, 他：間脳下垂体系異常の 是われる Pycnodysostosis の1例. 小児科臨床 33: 22-32 1970.

24）柴田大法，松矢浩司：Pycnodysostosis の 1 例. 中部整災誌 14：159-162 1970.

25) Shiraishi, S.: Pycnodysostosis (dysostosis petrosans). Acta Orthop Scand 42: 227-243 1971.

26）白石悟，松永住: Pycnodysostosis と思わ れる 3 症例 (抄)。日整会誌 46：295 1972 .

27）杉浦保夫, 山田傾亮, 他: Pycnodysostosis. 臨 整外 16：483-499 1971.

28) 藤谷正紀, 原田裕朗, 他：Pycnodysostosis の 1 例. 北海道整災誌 16：156-162 1971.

29）瀬野庄助，布施利二郎，他：Pycnodysostosis $の$ 1 例 (抄). 日整会誌 45:471 1971 .

30）菱田 豊, 須藤容章, 他: Pycnodysostosis 91 例(抄). 日整会誌 47: 4701973 .

31) 伊地知正光, 高橋 力, 他: Pycnodysostosis $の$ 1 例 (抄)。日整会誌 47:549 1973.

32) 斎藤 篤: Pycnodysostosis 91 例. 整形外科 24: 215-218 1983.

33）田辺智子，白順而夫，他：家族的発生をみた Pycnodysostosis 骨代謝 6：123-125 1973.

34) Yamada, N., Inomata, H., et al.: Two cases of Pycnodysostosis with special emphasis on maxillo-facial findings. Dent Maxillofac Radiol 2: 12-17 1973.

35) 石田了久，井上哲郎，他：Pycnodysostosis の 1 例. 関東整炎誌 5：148-154 1974 .

36) 岸彰, 有田ミェ, 他: Pycnodysostosis $の$ 同 胞例. 小児科臨床 27：75-80 1974.

37）志村介三，木下鞖彦，他：顎部症状をともなっ た Pycnodysostosis の 1 例. 日口外誌 $22: 523-$ 5331976.
38）西山章次，橋本真侍，他：Pycnodysostosis の 2 症例. 臨故 22: 219-223 1977.

39) Kawahara, K., Nishikiori, M., et al.: Radiographic observation of Pycnodysostosis. Oral Surg 44: 476-482 1977.

40) 中田 監, 横田 清: Pycnodysostosis. 臨放 22: 225-229 1977 .

41）岸 幹二，後藤俊文，他：若年者に発現した Pycnodysostosis のエックス線写真的観察. 迷 放 19: 54-58 1979 .

42）兼松 登, 吉田幸子, 他: Pycnodysostosis の 2 症例。口科誌 29: 127-135 1980.

43) Takeuchi, K., Tanne, K., et al.: Pycnodysostosis: Oral and Cranio-Facial Findings of 2 cases. J Osaka Univ Dent Sch 20: 317-336 1980.

44）花沢康雄, 石山信之, 他：Pycnodysostosis一症 例報告と本邦症例の統計的㘥察。日口外誌 29 : 151-158 1983.

45）藤井信男, 山城正宏 : 上下顎骨骨䯣炎を合併乙 た Pycnodysostosis の 1 例 (抄). 日口外誌 29: 1525-15261983.

46）今井幸一, 松本清弘, 他: 抜鄫後治瘾不全をお こした Pycnodysostosis の1症例 (抄). 口科 誌 32: 843-844 1983.

47) 矢島幹人, 山崎 正, 他 : 病的骨折をともな い, 同胞性にみられた Pycnodysostosis. 日口外 誌 31: 341-350 1985.

48）安田勝裕, 佐藤 圭, 他: Pycnodysostosis の 1 例. 日外誌 $34: 1668-16741988$.

49)田中博, 佐々木 淳, 他: 拔創の治痹不全 を生じた大理石骨病と思われる1例，日ロ外訰 28: 1188-1193 1982 .

50) 森恵造, 泜川裕之, 他: 大理石骨病に併発 した難治性顎骨骨骾炎の1例。日口外誌 30 : 1844-1848 1984 .

51）藤田恒太郎：歯の解剖学. 第17版, 金原出肘, 東京, 1971. 27-87頁. 